\title{
The Grotesque and Physical Degeneration in Franz Kafka's The Metamorphosis
}

\author{
Abdullah M. Dagamseh ${ }^{1} \&$ Faisal Rawashdeh ${ }^{2}$ \\ ${ }^{1}$ Yarmouk University, Department of English, Irbid, Jordan, 211-63. \\ Email: dagamseh@yu.edu.jo. https://orcid.org/oooo-ooo1-7479-1253 \\ ${ }^{2}$ Yarmouk University, Department of English, Irbid, Jordan, 211-63. \\ Email: faisal.rawashdeh@yu.edu.jo
}

Received August 03, 2018; Revised October 13, 2018: Accepted October 27, 2018; Published November o3, 2018.

\begin{abstract}
The question of the grotesque and theories of degeneration emerged in late $19^{\text {th }}$ century Europe and the early decades of the $20^{\text {th }}$ century. We argue that in The Metamorphosis, Franz Kafka uses the grotesque and physical degeneration to express a corresponding anxiety about the continuing physical retrogression of Man in the twentieth-century. Moreover, we claim that Kafka's main character, Gregor, is an entropic body reversing the biological bases of evolution and progression as theorized by many Darwinian evolutionists and Victorian social scientists. In allowing space for the articulation of organic degeneration, Metamorphosis not only attests to the sentiments of $19^{\text {th }}$-century degenerationists and their predictions of the continuation of this neurotic cycle of retrogression in the following century but also complicates the gothic representation of physical decline by bringing the grotesque into a high degree of prominence. Our reading of Kafka's novella is informed by Wolfgang Kayser's and Kelly Hurley's insights on the subjects of the grotesque and degeneration.
\end{abstract}

Keywords: Kafka, Metamorphosis, Grotesque, Degeneration, Entropic.

\section{Introduction}

The question of the grotesque and theories of degeneration emerged in late $19^{\text {th }}$ century Europe and the early decades of the $20^{\text {th }}$ century. According to Kelly Hurley (1996), these decades witnessed an "anxiety about the nature of the human identity," which was "generated by the scientific discourses, biological and sociomedical" (p. 5). These discourses, he adds, served to "dismantle conventional notions of the human" as a species belonging to a different, superior rank (p. 5). Unlike Matthew Powell (2008), who argues that the grotesque in Kafka's works is used to "explore the nature of otherness in the modern Western world" (p. 130), we claim, following from Hurley, that in The Metamorphosis, Franz Kafka uses the grotesque and physical degeneration to express a corresponding anxiety about the retrogression of Man in the twentieth-century. Moreover, we claim that Kafka's main character, Gregor, is an entropic body reversing the biological bases of evolution and progression as theorized by many Darwinian evolutionists and Victorian social scientists. In allowing space for the articulation of organic degeneration, Metamorphosis not only attests to the sentiments of $19^{\text {th }}$-century degenerationists and their predictions of the continuation of this neurotic cycle of retrogression in the following century but also complicates the gothic representation of physical decline by bringing the grotesque into a

(c) AesthetixMS 2018. This Open Access article is published under a Creative Commons Attribution Non-Commercial 4.0 International License (http://creativecommons.org/licenses/by-nc/4.0/), which permits non-commercial re-use, distribution, and reproduction in any medium, provided the original work is properly cited. For citation use the DOI. For commercial re-use, please contact editor@rupkatha.com. 
high degree of prominence. Our reading of Kafka's novella is informed by Wolfgang Kayser's (1957) and Kelly Hurley's (1996) insights on the subjects of the grotesque and degeneration.

\section{Theoertical Backgrouand and Review of Related Literature}

In recent scholarship on Kafka, the subjects of the grotesque and physical degeneration in The Metamorphosis (1915) remain not thoroughly researched and partly ignored. Without chiefly addressing the subject of the grotesque in The Metamorphosis, Matthew Powell (2008), for instance, studies Kafka's animal stories to argue that the grotesque in the latter's fiction serves in its entirety as an "expression of an ontological reality that indicates a precarious relationship between the self-and the world" (p. 130). In his analysis, he does not situate the grotesque in the context of $19^{\text {th- }}$ century discourse on degeneration and the continuation of the neurotic cycle of retrogression in the $2 \mathrm{o}^{\text {th }}$ century. Also, Michah Sadigh (2017) examines Kafka's Metamorphosis as a narrative of the grotesque that deals with the absurdity of "the human condition" and "what it means to be an existing individual" (p. 371). However, he does not read Kafka's protagonist, Gregor, as an example of a modern entropic figure. Other critics, like Karla Minar and A. Sutandio, use Sartre's notion of shame and alienation to chiefly address the socially alienating effects and factors of Gregor's transformation. i $^{\text {in }}$

In his influential study of the grotesque, Kayser traces the historical development of the grotesque from the fifteenth century, through the Romantic age, and up until the twentieth century. The grotesque, according to Kayser (1957), was simply the representation of human figures in "caricatural exaggerations" (p. 61), which were both humorous and horrific. The point then was to ornamentally exaggerate the representation of the human form. In these artistic representations, a human being would look more like a human-animal; the animalistic was disclosed in the human form, and the fusion of both the animalistic and the human features brought into question issues about the humanness of man and his relationship to his environment. With the dawn of the twentieth century, the grotesque found its way through gothic and horror stories, especially German fiction. The driving force behind this was the general belief that we are "strongly affected and terrified because it is our world which ceases to be reliable, and we feel that we would be unable to live in this changed world" (Kayser, 1957, pp. 1845). At some point in his The Grotesque in Art and Literature, Kayser (1957) argues that, through all these ages, the grotesque was not simply a mode of artistic or literary representation; it was, he contends, a "structure" (p. 148). The nature of the grotesque as a structure necessarily represents an "estranged world" (p. 184). He further adds that "suddenness and surprise" are two essential elements of the grotesque (p. 184).

These observations tie in with the theories of degeneration and disintegration rather than with evolution and progress. In his The Gothic Body: Sexuality, Materialism, and Degeneration at the Fin de Siècle, Kelly Hurley (1996) situates the revival of the Gothic fin-de-siecle within a "general anxiety" about the human subject in late-Victorian and Edwardian societies. He argues that the revival of such genre, its horrific representation of the human body in different animalistic forms, correspondingly reflects a literary anxiety about the identity of Man and his gradual deterioration in a modern, alienating world. We are interested in the theoretical background of degeneration that Hurley uses in his discussion of the decline of the human body in an evolving modern world of alienation and estrangement. We are not suggesting that Kafka's Metamorphosis can be categorized as a representative gothic work of art since the most essential feature of a gothic story-horror-is downplayed in Kafka's novella. The supernatural, too, is domesticated; in other words, the physical transformation in the novella does not take place in a 
haunted castle or monastery or vault but rather in a typical family house of two parents, a son, and a daughter. Terror is domesticated, familiarized, and given an unusual grotesque shape. In Kafka's novella, the body assumes a degenerate, grotesque form and is thus alienated and cast aside.

\section{Grotesqueness, Degeneration, and Anxiety}

In Metamorphosis (1915), terror is downplayed, and the grotesque is combined with humor. Readers are allowed some amusing moments in the story, which include humorous incidents that have to do with the protagonist's reaction to his own metamorphosis. In the early hours of the morning, and after waking up, Gregor Samsa is not typically appalled by his own physical deformity (he is transformed into a gigantic insect), but rather worried about how late he is for work. He even tries to get up and get himself dressed as quickly as possible to catch the early train for work. As readers, we find this absurdly amusing, and we empathize with his own dilemma, but we are never caught in moments of derision or ridicule against the plight of the hero. The combination of grotesque and humor becomes a literary technique and is employed structurally as a form of representation. Kafka invests in this literary mode to depict the existential absurdity of the whole metamorphic situation and its attendant consequence of estrangement and social alienation. In other words, Kafka expresses this anxiety about the existential dilemma of Man through the representation of the grotesque human. Hurley (1996) tends to situate the resurgence of fin-de-siecle gothic literature within the context of the European concern for the human subject and its being exposed to a plethora of changes (political, social, economic) in a late nineteenthcentury world. According to Hurley, European culture introduced to us entropic bodies, contrary to what evolutionism had already proposed with regards to the organic regeneration of the human subject (p. 67). Through its representation of corporeal grotesqueness, Kafka's Metamorphosis expresses a corresponding anxiety about the identity of man in the modern world. This anxiety is expressed through the representation of corporeal deformations and the attendant existential dilemmas. In Kafka's novella, a human being grotesquely degenerates rather than evolves.

Degeneration is the "particular plague of modernity, of those European nations that prided themselves on their high state of evolution" (Hurley, 1996, p. 73). Furthermore, the "symptoms" of degeneration develops with the advent of modernity. The primary cause of such development, Hurley (1996) adds, is "distinguished from the ancient by these five characteristics: steam-power, the periodical press, the telegraph, the sciences" (p. 74). Quoting other degeneration theorists, such as Max Nordau, Hurley (1996) mentions that the first generation of the modern age "was subjected to such new and stressful phenomena as crowded urban living, railway travel" (p. 74). He also points out how "daily newspapers had grown hysterical" and how "the next generation had inherited that hysteria" (p. 74). This sense of hysteria induced physical fatigue and, most importantly, "organic degeneration" (Hurley, 1996, p. 74).

This implosion of modernity, it seems, has a very radical effect on Gregor as one who belongs to the twentieth-century generation. Quite interestingly, Gregor himself expresses a similar anxiety (tinged with feelings of fatigue and boredom) over the incessant, and almost hysterical, daily travels to get to work. Now a gigantic insect still struggling to get up and go to work, Gregor expresses his anger and stresses his physical exhaustion with regards to his job and the hysterical daily train commutes:

'O God,' he thought, 'what a demanding job I've chosen! Day in, day out on the road. The 
stresses of trade are much greater than the work going on at head office, and, in addition to that, I have to deal with the problems of traveling, the worries about train connections, irregular bad food, temporary and constantly changing human relationships which never come from the heart. To hell with it all!' (1915, p. 4)

Interestingly, Gregor is preoccupied more with the hectic whirlpool of his daily routine than with his current corporeal transformation. Gregor's situation attests to the modern hysteria that Hurley associates with the "organic degeneration" of modern Man. What can be more physically degenerative than the transformation of the human subject into a gigantic insect? The hysteric nature of modernization has already reduced Gregor into a vermin-like creature. According to Hurley (1996), modern age reduced Man to a species struggling obsessively to survive; this reduction is concretely represented in many gothic stories where the human body "collapses and is reshaped across a wide range of morphic possibilities: into slug-men, snakewomen, ape-man, beast-people, octopus-steal-men, beetle-women, dog-men, fungus people” (p. 4). The metamorphosis of Gregor into an insect, we suggest, is a continuation of these morphic possibilities and is a demonstration of the hysteric, hectic nature of the modern era characterized by a neurotic lifestyle.

Hurley (1996) makes clear how degenerationism "substituted" the idea of biological evolution with a "terrible regression, a downward spiral into madness, chaos, and extinction" (p. 66). Such theory reverses the line of human progression: Man gradually degenerates from human to animal, and from modern to savage. Hurley's historical account of degeneration is of great importance with regards to the corporeal metamorphosis of Gregor, a representation of the twentieth-century entropic body and a demonstration of the existential chaos of the modern age. Gregor's retrogression attests to these scientific predictions which Hurley talks about in his discussion of the entropic bodies of late nineteenth-century and the early decades of the twentieth-century. Hurley (1996) maintains that nineteenth-century scientists "pointed towards the possibility, even the inevitability, of changes within the physical or social environment that would irrevocably reshape the human form and human culture" (p. 65). He adds that "evolutionism, and social medicine generated the highly compatible models of entropy, species reversion, and human pathology," and it "became clear then that these alterations would be disastrous ones as it would transform the human species into something unrecognizable, perhaps even ensuring its extinction" (p. 65). Based on Hurley's historical and theoretical account on degeneration, we claim that Kafka's Gregor can function as an example of entropy. In other words, Kafka's Metamorphosis (1915) is an articulation of the scientific predictions purported by the degenerationists who expressed their anxiety about the cultural chaos and the physical retrogression of Man. We believe that Gregor's transformation counts as one of the best literary examples of a twentieth century cultural entropy, whose apt representation started, as Hurley argues, in the very late decades of nineteenth century fiction.

In fact, Kafka is concerned not so much with the gothicism of metamorphosis as with its grotesque realism and the consequent social and personal complications. In Metamorphosis, there are no monsters or ape-men residing in subterranean mazes whose mysteries are soon to be unraveled through the divulgement of a family secret that is hidden for long by a suspect individual involved in a murder or in unpleasant romantic escapades. In Kafka's novella (1915), there is a middle-class family sustained by a son, who wakes up "one morning ... from anxious dreams" and finds himself "changed into a monstrous verminous bug" (p. 3). We are led into this grotesque reality from the very beginning of the story; Gregor's deformed body looms large on account of its repulsive gigantism and unexpected intrusion. Kafka relies heavily upon shock to 
establish as much grotesqueness as possible. For him, the grotesque does not only mean the physical repulsiveness of the entropic body; it also means the introduction of the element of shock or what Wolfgang Kayser (1957) calls "surprise and suddenness (p. 148).

Kafka invests in these elements of suddenness and surprise to represent an estranged world where the entropic body of Gregor undergoes a gradual process of degeneration. Gregor has been suddenly transformed into an insect: "One morning, as Gregor Samsa was waking up from anxious dreams, he discovered that in bed he had been changed into a monstrous verminous bug" (1915, p. 3). At first, Gregor is able to maintain a humanlike articulation of sounds, though his family thinks that he must be ill owing to the strangeness of his voice. His family thinks that the reason why he stays in his room is because of some physical illness. The mother told the manager, "He is not well, believe me Mr. Manager. Otherwise how would Gregor miss a train? ... he's certainly not well, although he denied that this morning" (1915, p. 15). Later on, his articulation of sounds, his ability to speak like a human, is totally lost and is only able to produce "persistent, horrible twittering squeaks" (1915, p. 91).

His gradual degeneration becomes extreme when he can no longer eat any type of food that humans usually eat: "Gregor ate hardly anything any more. Only when he chanced to move past the food which had been prepared did he, as a game, take a bit into his mouth, hold it there for hours, and generally spit it out again" (1915, p. 75). Instead, he enjoys eating the leftovers of some rotten food. He is also seen struggling to get up and crawl around the room but gradually becomes accustomed to moving around and using his multiple legs to eat, scratch, and climb across walls. This gradual degeneration contributes to his family's neglect and lack of empathy. At the end of the novella, his family members start to refer to him as the "it" that "must be gotten rid of ... you must try to get rid of the idea that this is Gregor," Gregor's sister told her parents (1915, pp. 85-86). The absence of human contact and sympathy contributes to this case of extreme physical and spiritual human decline.

Kayser (1957) explains how the grotesque can be fully present in any literary narrative through "the observation of a soul in the process of being estranged from itself and ineluctably bound for destruction" (p. 143). This observation is related to the discourse of the degenerationists who contend that the physical and social alterations of the modern human might ensure his extinction. This ultimate dissolution is readily observable in Kafka's Metamorphosis (1915): the gradual degeneration of Gregor's entropic body goes through stages of adaptation, estrangement, and finally extinction. Gregor's life ends with a decision that he must vanish permanently as his presence has already brought chaos into the lives of his own family:

He thought of his family with tenderness and love. The decision he must disappear was one that he held more strongly than his sister, if that were possible. In this state of vacant and peaceful meditation he remained until the tower clock struck three in the morning. The first broadening light in the world outside the window entered his consciousness once more. Then his head sank to the floor of its own accord and from his nostrils came the last faint flicker of his breath. (1915, p. 135)

Gregor's death is inevitable in this grotesque realism of metamorphic possibilities. His metamorphosis results in his alienation and estrangement as a species belonging to the ranks of insects. Kayser (1957) contends that "the disclosure of the animal in man usually intensifies the effect of alienation" in this world (p. 132), and this is what Gregor experiences as his degenerative status exposes him to stages of ostracism and marginalization. He is left alone in his room and is attended to by his sister who brings him food and cleans his room once in a while. At first, she is very reluctant to go into the room but is driven by sibling compassion to at least help him survive. 
Later on, she feels disgusted and tired of Gregor as she sees him as an "animal [that] plagues us" (1915, p. 86). Here Gregor is no longer a human being.

In an attempt to re-establish emotional connection with his family, and to reduce the effects of this sudden, unexpected transformation, Gregor leaves his room three times. However, his attempts to communicate with his family and his manager always fail as both the family and the manager are unable to come to terms with his metamorphic condition. He leaves the room for the first time when the manager comes by the Samsa's house to inquire as to why Gregor is late for work: "But at Gregor's first words the manager had already turned away, and now he looked back at Gregor over his twitching shoulders with pursed lips" (1915, p. 26). The manager then moves "away towards the door, without taking his eyes off Gregor" (1915, p. 26), and the suddenness "with which he finally pulled his foot out of the living room, one could have believed that he had just burned the sole of his foot" $(1915$, p. 26). Still trying to catch the manager, Gregor follows him but the manager "must have suspected something, because he made a leap down over a few stairs and disappeared, still shouting 'Huh!' The sound echoed throughout the entire stairwell" (1915, p. 29). Gregor fails to establish any connection with the manager as the latter feels repulsed by Gregor's appearance and can't stand even talking to him to understand what has happened to him.

His family members are not better at communicating with Gregor. While calling "Mother, mother" in a low voice, Gregor advances toward his mother, who has already sprung up to her feet with arms and legs outspread screaming "Help, for God's sake, help" (1915, p. 28). Appalled by the grotesqueness of the situation, the mother "screamed all over again, hurried from the table, and collapsed into the arms of his father, who was rushing towards her" (1915, p. 29). In the meantime, the father got mad at Gregor because the manager immediately left their house feeling horrified and disgusted by the grotesque appearance of Gregor. The father was aggressive towards his son: "with his right hand he grabbed hold of the manager's cane ... with his left hand, [he] picked up a large newspaper from the table and, stamping his feet on the floor, he set out to drive Gregor back into his room by wavering the cane and the newspaper" (1915, p. 29). Finally, his father violently drives Gregor back to his room, and now Gregor is "bleeding severely far into the interior of his room" (1915, p. 32).

Gregor leaves the room for the second time trying to connect with his family members; however, he even maddens his family. For example, his father, after knowing that Gregor's grotesque appearance makes his mother faint, bombards him with apples and drives him back again into the room. This takes place when Grete and her mother are busy cleaning Gregor's room and removing the furniture from his room; Gregor does not like the fact that his family is trying to get rid of his furniture, especially the picture of the pretty lady with "a fur hat and a fur boa" (1915, p. 3). In an attempt to protect his own possessions, he jumps out from underneath the couch, and upon spotting him on the wall, the mother faints. Then, he leaves for "the next room" as he can remain away from his mother: "She slammed the door shut with her foot. Gregor was now shut off from his mother, who was perhaps near death, thanks to him. He could not open the door, and he did not want to chase away his sister who had to remain with her mother" (1915, pp. 59-60). Thus, his second attempt to get closer to his family has failed, too.

Leaving the room for the third time when his sister is playing the violin to her parents and to the lodgers, Gregor experiences total disappointment and loneliness. Apparently enjoying listening to the melodious tones of the violin and eager to communicate with his sister, he stealthily walks out from the room. Once Gregor is spotted by the lodgers at his family's house, the father feels embarrassed and ashamed of his son's appearance: “The father hurried over to 
them and with outstretched arms tried to push them into their own room and simultaneously to block their view of Gregor with his own body" (1915, p. 82). Gregor is later chased back into the room whose door is locked with irritation and disgust. It is right after this incident when the lodgers, horrified and disgusted by Gregor appearance, threaten to press charges of damages. One of the lodgers stated:

I hereby declare ... that considering the disgraceful conditions prevailing in this apartment and family ... I immediately cancel my room. I will, of course, pay nothing at all for the days which I have lived here; on the contrary I shall think about whether or not I will initiate some sort of action against you, something which - believe me - will be very easy to establish. (1915, p. 83)

Now suffering total alienation and frustration, Gregor is incarcerated in his room, and his sister is presiding over a family meeting in which she decides that they should get rid of this creature as soon as possible, expressing her own indignation and frustration with the whole situation:

'It must be gotten rid of,' cried the sister; 'That is the only way, father. You must try to get rid of the idea that this is Gregor. The fact that we have believed for so long, that is truly our real misfortune. But how can it be Gregor? If it were Gregor, he would have long ago realized that a communal life among human beings is not possible with such an animal and would have gone away voluntarily. Then we would not have a brother, but we could go on living and honour his memory. But this animal plagues us. It drives away the lodgers, will obviously take over the entire apartment, and leave us to spend the night in the alley. Just look, father,' she suddenly cried out, 'he's already starting up again.' (1915, p. 86)

Everybody feels disgusted and annoyed by the presence of Gregor, including his sister who used to take care of and communicate with him. He has nobody left for him.

Upon hearing his sister's complaints, Gregor thinks he must die to relieve the family from his grotesque burden. His extinction as a metamorphic species is inevitable since he is alienated from his own family and cannot go on living in an estranged world. Before his metamorphosis, the family used to depend upon him for sustenance, but after this unpredictable transformation, he is no longer capable of providing the least amount of help. His grotesque appearance drives the lodgers away, hence depriving his family of another source of income. Gregor has led a very exhausting life in the first place, and his alienation and isolation as a vermin-like creature incapable of sustaining the family mirror his own alienation as a commercial traveler who is consumed by the demands of work and the commands of his manager.

One can say that Gregor's dilemma manifests itself in a physical deformation that reflects his major plight as a modern Man worn off by the alienating aspects of labor. At some point, Gregor shows his indignation of the manager and his job, and he imagines how he would be able to leave his job once he pays back his parents' debt:

[W] hat a demanding job I've chosen! Day in, day out on the road. The stresses of trade are much greater than the work going on at head office, and ... I have to deal with the problems of traveling, the worries about train connections, irregular bad food, temporary and constantly changing human relationships which never come from the heart. To hell with it all .... If I didn't hold back for my parents' sake, I would've quit ages ago. I would've gone to the boss and told him just what I think from the bottom of my heart .... Once I've got together the money to pay off the parents' debt to him - that should take another five to six years - I'll do it for sure. Then I'll make the big break. (1915, pp. 4-5) 
Although he has already been transformed, Gregor is still worried about arriving late to work. This tinge of humor demonstrates Gregor's existential plight and his struggle to survive in an estranged reality. According to Ramon Mendoza (2011), Gregor's alienation as a modern human subject has already intensified once he has been transformed into some monstrous vermin ( $p$. 136). He is already alienated, and his physical deformation is a translation of his extreme sense of estrangement and a biological reaction to the hysteric reality of the modern world.

What is extremely comical is Gregor's own natural reaction to his transformation. It seems that he considers his own metamorphosis as being a natural corollary to the alienating process of labor. Instead of being horrified at his own transformation, he simply turns his thoughts to the troubles of work and seems rather absurdly at ease with his own new condition. Every bit of detail about his metamorphosis reflects helplessness and struggle. The description at the very beginning of the story represents the comic side of his physical grotesqueness:

One morning, as Gregor Samsa was waking up from anxious dreams, he discovered that in bed he had been changed into a monstrous verminous bug. He lay on his armour-hard back and saw, as he lifted his head up a little, his brown, arched abdomen divided up into rigid bow-like sections. From this heights the blanket, just about ready to slide off completely, could hardly stay in place. His numerous legs, pitifully thin in comparison to the rest of his circumference, flickered helplessly before his eyes. (1915, p. 3)

Despite their grotesqueness of representation, these lines (and so many others as well) demonstrate what Kayser (1957) sees as an important factor of the grotesque in any literary representation. He contends that any grotesque literary representation serves to assert that "humor and terror are twin children of their mother imagination, since both are suspicious of mere facts and distrust any rationalistic explanation of the world" (p. 139). We, as readers, are not allowed any rationalistic explanation of the physical transformation of Gregor, whose comical reaction runs counter to the terrified reaction of the family and the manager. We are never told why Gregor has been transformed into an insect, nor are we able to explain Gregor's reconciliation with this physical deterioration.

One way to explain Gregor's and his family members' reconciliation with the former's physical transformation is what Jenni Adams (2011) refers to as the "acceptance of magic" (p. 8). In a magic realist world, the characters, and the author as well, do not "express surprise" at any supernatural incident. Magic becomes part of reality and is accepted as something very normal and ordinary. The author even does not comment on the bizarre occurrence; this "authorial reticence" preserves the ordinariness of the extraordinary situation (Adams, 2011, p. 8). Magic becomes as ordinary as any realistic incident. In Metamorphosis, the authorial reticence is one important feature of this magic realist world of the novella, which Adams (2011) mentions as a representation of a reality where the transformation of Gregor is taken as a "minor inconvenience" (p. 9). For example, Gregor himself does not panic and does not show any surprise when realizing that he has "been changed into a monstrous verminous bug" (1915, p. 3). He only notes "his armour-hard back" and "his brown, arched abdomen" (1915, p. 3).

\section{Conclusion}

It is true that Gregor's family members are appalled by such a preternatural incident, yet their terror is ascribed to the repulsiveness of the situation rather than to its extraordinariness. Gregor has been transformed into an insect, yet this transformation is dealt with in a manner that would suggest acceptance on the part of the family. It is as if the very fact of metamorphosis in the text 
could happen to anyone. It is even very funny how the cleaning woman reacts when she spots Gregor in his room sitting still next to the couch: "Come here for a bit, old dung beetle!" (1915, p. 74). The cleaning woman not only reconciles herself with this huge beetle but also seems to admire its grotesque shape: "Hey, look at the old dung beetle!" (1915, p. 74).

In fact, humor is used as a narrative technique and is an "alienable part of the grotesque" (Kayser, 1957, p. 140). The combination of the horrific and the humorous is necessary for the grotesque representation of reality. In Metamorphosis (1915), the entropic body is both humorous and horrific. It is represented to be terror-striking for the family, especially for the mother, and funny-looking for the cleaning woman and the lodgers. The grotesque thus incites different emotions, and this is part of its absurd nature and its ability to shake, to use Kayser's (1957) words, "the reader's confidence in his world view by depriving him of the safeguards provided by tradition and society" (p. 61). In Metamorphosis, the grotesque is a structure of representation used by Kafka to introduce to us a continuing degeneration of the modern human body whose retrogression, rather than evolution, describes a neurotic, hysterical era whose conditions foster "fear of life rather than fear of death" (Kayser, 1957, p. 15). And this is what characterizes Gregor's family and Gregor's world as everybody welcomes Gregor's death rather than laments it. Gregor's transformation and his subsequent alienation and death count as one apt literary example of a twentieth-century cultural entropy that began to take shape in the preceding centuries.

\section{Notes}

${ }^{i}$ For more scholarship on Kafka, see the following texts: John Zilcosky's Kafka's Travels: Exoticism, Colonialism and the Traffic of Writing, Walter H. Sokel's "Beyond Self-Assertion: A Life of Reading Kafka," Simon Ryan's "Franz Kafka's Die Verwandlung; Transformation, Metaphor, and the Perils of Assimilation," and Sander Gilman's Franz Kafka, the Jewish Patient. These texts examine Kafka's works in terms of culture, race, ethnicity, gender, and history.

\section{References}

Adams, J. (2011). Magic realism in holocaust literature: Troping the traumatic real. NY: Palgrave.

Gilman, S. (1995). Franz Kafka, the Jewish patient. New York: Routledge.

Hurley, K. (1996). The gothic body: Sexuality, materialism and degeneration at the fin de siecle. Cambridge: Cambridge UP.

Kafka, F. (1999). The Metamorphosis. (Ian Johnston, Trans. by Ian Johnston). (Original work published 1915). Retrieved from https://www.planetebook.com/free-ebooks/the-metamorphosis.pdf.

Kayser, W. (1957). The grotesque in art and literature. Bloomington: Indiana UP.

Mendoza, R. (2012.) The human vermin: Kafka's metaphor of extreme alienation. In J. Whitlark (Ed.), Critical Insights (pp. 133-165). Pasadena, CA: Salem Press.

Minar, K. S. and A. Sutandio (2017). Shame and alienation in Kafka's The 
Metamorphosis. Poetika: Jurnal Ilmu Sastra, 5, (32), 123-133.

Powell, M. T. (2008). Bestial representations of otherness: Kafka's animal stories. Journal of Modern Literature, 32 (1), 129-42.

Sadigh, M. (2017). The nightmare of becoming human: Metaphors and reflections for individuals in search of authentic self. Existential Analysis, 28 (2), 362-373.

Ryan, S. (2007). Franz Kafka's die verwandlung; transformation, metaphor, and the perils of assimilation." Seminar, 43 (1), 1-18.

Sokel, W.H. (2002). Beyond self-assertion: A life of reading Kafka. In J. Rolleston (Ed.), A Companion to the Works of Franz Kafka, Edited by James Rolleston. Rochester: Camden House.

Zilcosky, J. (2003). Kafka's travels: Exoticism, colonialism and the traffic of writing. New York: Palgrave Macmillan. 